\title{
On the major behavioral motivation factors of the kazakh national military formations' soldiers during the war (1941-1945)*
}

DOI: $10.31551 / 2410-2725-2019-5-2-280-295$

\section{Asanova Saltanat Amirgalievna}

Candidate of Historical sciences, Leading Researcher at the Ch.Ch.Valikhanov Institute of History and Ethnology. of CS MES RK, Department of the History of Kazakhstan of the Soviet period, Kazakhstan, Almaty, Shevchenko str., 28. E-mail: saltasanova@gmail.com

Abstract. The article is devoted to finding an answer to the question about the main factors of the behavioral motivation of the Kazakh soldiers in the first, most tragic period of the war.

This motivation was the basis of high civic consciousness of Kazakh soldiers, officers and members of the labor front. An attempt was made to ethnological analysis of the main factors of the moral mobilization of the Kazakh people on the example of national military units.

According to the author, namely, the ethnological approach to the studied issues allows to identify the socio-psychological phenomenon that provided a high patriotic rise of the Kazakh military and their readiness for voluntary sacrifice in the name of Victory.

It is noted that the former explanatory practices that linked the sources of victory with the indisputable advantage of the Soviet system and the popular support of the Soviet government do not satisfy and do not correspond to the modern level of historical knowledge. The pre-war period associated with violent modernization did not give grounds for the formation of Soviet patriotism. Today, Kazakh historians are unanimous in the negative assessment of the power-based nature of Soviet modernization, which has turned into irreplaceable physical and more important for ethnocultural losses for Kazakhs. The Kazakhs paid a very high price for the tragic experience of modernization. However, despite all the insults caused by the Soviet authorities, the Kazakhs, from the very first tragic period of the Great Patriotic War, became one of the best soldiers of the Red Army and made an invaluable contribution to the Victory.

Essentially, the author's efforts boil down to finding an answer to the question of the main and real factors of the behavioral motivation of the Kazakh soldiers, since from the point of view of rational logic, the participation of the Kazakhs in this war was a definite historical paradox. Particular attention is paid to defining the main vectors of changing the content of propaganda work during the first most tragic period of the war, as well as analyzing the peculiarities of the internal policy (national and religious) of the Soviet government, first of all, its aspects such as addressing national and religious values that stimulated a positive mobilization motivator people

Key words: national policy, mobilization, national military formations, patriotism, internationalism, chauvinism, nationalism

\section{Соғыс жылдарындағы қазақ ұлттық әскери құрама жауынгерлерінің мінез-құлық уәждемесінің негізгі себептері туралы (1941-1945)}

\section{Асанова Салтанат Әмірғалиқызы}

Тарих ғылымдарының кандидаты, жетекші ғылыми қызметкер, ҚР БҒМ ҒК Ш.Ш. Уәлиханов атындағы Тарих және этнология институты, «Кеңес дәуіріндегі Қазақстан тарихы» бөлімі, Қазақстан, Алматық., Шевченкок., 28 үй. E-mail: saltasanova@gmail.com

Аңдатпа. Мақала соғыс кезіндегі қазақ халқының патриоттық өрлеуі мен оның өз еркімен құрбандыққа баруының негізгі қайнаркөздерін ұлттық әскери құрамалар арқылы саралауға арналған. Жеңістің қайнар көздерін кеңестік құрылыстың артықшылықтарымен және кеңес өкіметін бүкіл халықтық қолдау негізінде бұрынғыша түсіндіру тәжірибесі бүгін қанағаттандырмайды және тарихи білімнің қазіргі деңгейіне сәйкес келмейді. Соғысқа дейінгі күштеп өзгеріске ұшырату кеңестік патриотизмнің қалыптасуына негіз бола алмайтын еді. Бүгіндері Қазақстан тарихшылары кеңестік модернизацияның күштеу сипатын бірауыздан

\footnotetext{
* Статья написана в рамках реализации проекта Национальные войсковые формирования Казахстана на фронтах войны (1941-1945 гг.)»
} 
айыптайды. Себебі ол қазақтар үшін орны толмас шығындармен этномәдени тоқырауға алып келді. Бірақ кеңес өкіметінің қазақ халқына келтірген қаншама сұмдық қиындықтарына қарамастан, қазақтар соғыстың алғашқы трагедиялық күндерінен бастап Қызыл Армияның ең таңдаулы солдаттарының қатарында болып, Жеңіске өлшеусіз үлес қосты. Авор негізінен қазақ жауынгерлерінің отанға беріле соғысу себептерімен оның шынайылығына жауап іздейді, себебі тиімді логика тұрғысынан бұл соғыс қақазақтардың қатысуының өзі тарихи парадокс сияқты еді. Мақалада соғыстың алғашқы трагедиялық кезеңінде үгіт-насихат жұмыстары ауқымының өзгеруіне ерекше назар аударылған. Мұның жауабын кеңес өкіметінің ішкі (ұлттық және діни) саясатын саралау арқылы білуге болады. Ең алдымен оның соғыс кезіндегі ұлттық және діни саясатындағы бет бұрыстан, халықтың жауға қарсы күрестегі жағымды психологиялық мүддесінен бұланық көрініс тапты.

Кілтсөздер: ұлттық саясат, мобилизация, ұлттық әскери құрамалар, патриотизм, интернационализм, шовинизм, ұлтшылдық.

\title{
Об основных факторах поведенческой мотивации воинов казахских национальных войсковых формирований в годы войны (1941-1945)
}

\section{Асанова Салтанат Амиргалиевна}

кандидат исторических наук, ведущий научный сотрудник отдела «Истории Казахстана советского периода», Институт истории и этнологии им. Ч.Ч. Валиханова КН МОН РК, Казахстан, Алматы, ул. Шевченко, д. 28. E-mail: saltasanova@gmail.com

\begin{abstract}
Аннотация. Статья посвящена поиску ответа на вопрос об основных фракторах поведенческой мотивации воинов-казахов в первый, наиболее трагический период войны. Эта мотивация явилась основой высокой гражданской сознательности казахских солдат, офицеров и участников трудового фронта. Предпринята попытка этнологического анализа основных фракторов моральной мобилизации казахского народа на примере национальных войсковых формирований.

По мнению автора именно, этнологический подход к исследуемой проблематике позволяет выявить социально-психологический феномен, обеспечивший высокий патриотический, подъем казахских военнослужащих и их готовность к добровольной жертвенности во имя Победы.. Отмечается, что прежние объяснительные практики, связывавшие истоки победы с неоспоримым преимуществом советского строя и всенародной поддержки советской власти не удовлетворяют и не соответствуют современному уровню исторического знания. Предвоенный период связанный с насильственной модернизацией не давал основания для формирования советского патриотизма. Сегодня казахстанские историки единодушны в негативной оценке силового характера советской модернизации, которая обернулась для казахов невосполнимыми физическими и что важнее этнокультурными потерями. Казахи заплатили очень высокую цену за трагический опыт модернизации. Однако, несмотря на все обиды, причиненные советской властью казахи, с самого первого трагического периода Великой Отечественной войны стали одними из лучших солдат Красной Армии и внесли неоценимый вклад в Победу. По - существу, усилия автора сводятся к поиску ответа на вопрос об основных и реальных фракторах поведенческой мотивации воинов-казахов, поскольку с точки зрения рациональной логики участие казахов в этой войне было определенным историческим парадоксом. Особое внимание уделено определению основных векторов изменения содержания пропагандисткой работы в первый наиболее трагический период войны, а также анализу особенности внутренней политики (национальной и религиозной) советской власти, прежде всего, таких ее аспектов как обращение к национальным и религиозным ценностям, стимулировавших положительную мобилизационную мотивацию воюющего народа.
\end{abstract}

Ключевые слова: национальная политика, мобилизация, национальные войсковые формирования, патриотизм, интернационализм, шовинизм, национализм. 
Удк/UDC 94(574) "1941/45"+572.9+35

\section{Об основных факторах поведенческой мотивации воинов казахских национальных войсковых фоомирований в годы войны (1941-1945)}

\section{C.A. Асанова}

Введение. Сложный и противоречивый процесс становления национальной концепции отечественной истории сопровождается отходом от прежней трактовки ее как части общесоюзной истории без учета собственной национальной специфики. Вместе с тем, существовавшие прежде объяснительные практики, связывавшие причины патриотического подъема казахского народа с неоспоримыми преимуществами социализма и верности советской власти отвечают современной концепции казахской истории. В этой связи основной задачей исследовательского дискурса стали поиски ответа на вопрос - чем реально мотивировался патриотический подъем казахского народа? А также - как шла трансформация идеологической парадигмы в условиях войны, какой фрактор морально-психологической мобилизации воюющего народа оказался решающим в поведенческой мотивации казахских солдат, обеспечивший эффрективность и боеспособность казахских национальных войсковых фрормирований на фрронтах войны.

Материалы и методы. Методологической основой статьи послужили традиционные для данного направления принципы историзма и научной объективности. Попытки выяснения реальных факторов моральной мобилизации казахских солдат потребовало использование других методологий. В частности, теории этноса, согласно, которой любые этнические образования являются результатом интеллектуальных конструкций. Они утверждаются в общественном сознании благодаря использованию государством комплекса средств массовой агитации и пропаганды, а также системы образования. Ситуационное использование конструктивизма при анализе национальных явлений выявляет роль государства в формировании общественных настроений и мотивов поведения. (Тишков, 1993: 5). Поэтому представляется оправданным и целесообразным применение этнологического подхода к проблеме выявления факторов патриотического подъема казахского народа в годы Великой Отечественной войны.

Вместе с тем предпринятая попытка этнологического анализа основывается на корреляции государственной политики гражданским обществом. Результатом действия таких противоречивых векторов в формировании общественного сознания становится появление новой парадигмы, способной решить самые грандиозные задачи. Ситуационное использование конструктивизма позволяет определить роль государства в формировании общественных настроений и мотивов поведения, а также обратной связи со стороны населения. Общество - это самоорганизующаяся структура. Современная историческая наука выявила пути, позволяющие приблизиться к пониманию исторического прошлого через его субъект и носителя - самого человека. Всесторонний анализ материальных и социальных форм повседневного существования человека - его жизненного микромира, стереотипов его мышления и поведения - рассматривается как один из возможных в этом отношении подходов. Представители Франксуртской школы, стремившиеся понять истоки тоталитаризма, указывали на организующую роль идеологий в структуре общественной жизни. 
Обсуждение. Как известно, В советский период тема Великой Отечественной войны была одной из самых востребованных. «По сведениям библиографов, по истории Казахстана периода Великой Отечественной войны опубликованы сотни книг, брошюр и журнальных статей. Только в одном 1965 г. в связи с 20-летием Победы вышло 8 книг, 24 брошюры и свыше 200 научных статей в журналах и республиканских газетах, отражающих вклад республики в разгром врага» (Козыбаев, Белан, 1991:20).Непосредственно в годы войны по горячим следам событий было положено начало изучению истории войны и тыла. Однако работам, опубликованным в 1941-1945 гг., как начальному этапу изучения истории войны, помимо преклонения перед И.В. Сталиным, был присущ агитационно-пропагандистский характер, нежели научный. В первое послевоенное десятилетие был сделан значительный шаг в исследовании истории Казахстана военных лет: в составе Института истории, археологии и этнографрии АН Казахской ССР была создана специальная научная ячейка - отдел истории Великой Отечественной войны во главе с А.Н. Нусупбековым (фронтовиком-панфиловцем, впоследствии академиком АН КазССР, вице-президентом АН Казахской ССР, с 1956 г. по 1982 г. директором вышеуказанного института), положившим начало научной разработке проблем истории военного времени, в том числе участия казахстанцев на фрронтах войны. Следующий этап - со второй половины 50-х годов XX в. до конца 1964 г. характеризовался значительным расширением документальной базы исследований на основе постановления ЦК КПСС, нацеливавшего соответствующие учреждения и ученых на разработку объективной истории военного времени. Труды А. Нусупбекова, М. Козыбаева, Т. Балакаева, М. Асылбекова, Н. Едыгенова, П. Белана, С.Н. Покровского и других знаменовали собой качественно новый этап казахстанской историографии войны. (Балакаев, Алдажуманов, 1989: 113-114). Вместе с тем даже несмотря на академический характер и фундаментальность источниковой базы выше перечисленные исследования сохраняли парадно-победоносный тон и интерпретацию событий, характерную для всей историографии советского периода. Трудности военного времени преподносились в «лакированном» фрормате. Исследователи не всегда могли показать реальную картину военной истории со всеми трагическими и сложными явлениями». (Алдажуманов,2011:204).

Постсоветский период так же знаменовался попытками отечественных историков осветить отдельные проблемы истории войны и участия в ней казахского народа. Основными объектами внимания были проблемы, которые ранее не затрагивались советской историографией, это так называемые «белые пятна» истории войны. В трудах ведущих отечественных специалистов Козыбаева М.К, Алдажуманова К.С., Балакаева Т.Б. впервые были подняты вопросы фоомирования и участия в боевых действиях национальных частей и соединений, история участия казахского населения в Трудовой армии, трагическая судьба казахских военнопленных, история движения Сопротивления и Туркестанского легиона. Таким образом, со времен обретения независимости немалую работу проделали и казахстанские историки. Под руководством выдающегося казахстанского ученого, академика М.К. Козыбаева было осуществлено издание сводного тома «Книги памяти Казахстана - Боздақтар» Книга Памяти Казахстана - Боздақтар. (Сводный том. Сост: Белан, Едыгенов:1995). При научно-методическом руководстве М. Козыбаева осуществлено издание «Книги Памяти» по областям Казахстана. В многочисленных работах М.Козыбаева нашли отражение новые 
методологические подходы освещения основных вех советской истории, в том числе и Великой Отечественной войны (Козыбаев, 2000: 34-40).

Значимую роль в казахстанской историографии сыграла публикация К.С. Алдажуманова «История войны 1941-1945 годов и Казахстан: белые пятна и проблемы». Автор статьи обозначил ключевые проблемы истории Великой Отечественной войны, определил проблематику и перспективы научно-исследовательских направлений. Текущий этап ознаменован реализацией научно-исследовательских проектов, поддержанных КН $\mathrm{MOH}$ РК по предложенной проблеме, научным руководителем выступает К.С. Алдажуманов.

Источниковая база исследуемой темы достаточно широко апробирована. Вместе с тем постсоветский период характеризуется своеобразной архивной революцией, связанной с открытием и доступностью большинства ранее закрытых фондов. РГАСПИ, ГАРФ, АП РК, ЦГА РК. Эти документы позволяют раскрыть реальную картину морально-психологического состояния воюющего народа. Однако, даже они не могут полностью удовлетворить исследовательские задачи в силу высокой степени идеологизированности. В качестве дополнительных источников служат индивидуальные воспоминания непосредственных участников, простых рядовых людей, которые были собраны в результате казахстанских научно-исторических экспедиций постсоветского времени, а также публикации зарубежных источников, воспоминаний участников коллаборационистского движения, а также других граждан, оказавшихся в западной зоне оккупации.

Результаты. Одним из самых сложных проблем общественной жизни советского государства на протяжении его семидесятилетней истории и до самого крушения был национальный вопрос. Острота национального вопроса возросла в условиях военно-политической катастрофы первых месяцев войны, когда за первые «18 месяцев гитлеровский вермахт нанес серьезный ущерб советскому государству и катастрофические поражения его Красной Армии. Германские вооруженные силы захватили 30 процентов европейской территории Советского Союза с ее огромным населением и богатой промышленной и сельскохозяйственной базой, 1 миллион 998 человек солдат и офицеров попали в плен за первые полгода войны. ${ }^{1}$ Трагическое начало войны фрактически привело к крушению Красной армии, которое, по мнению российских исследователей, было не только результатом внезапного нападения, тактических промахов советского руководства, но и подтверждением того фракта, что в сложившейся трагической ситуации широкое распространение получили паника, отчаяние, что в конечном счете, привело к массовой сдаче в плен.

Миллионы советских солдат и офицеров оказались в плену. Исход войны теперь зависел от населения тыловых, в том числе восточных районов страны. В 1942 году и до лета 1943 г. мобилизация шла только за счет восточных регионов. Формирование новых частей и соединений шло непрерывно. Из центрально азиатских республик в этот период было призвано на фрронт 3 млн. человек (Козыбаев,2000: 211). В условиях военного времени произошла перестройка идеологического содержания национальной политики, истоки которой лежат в 30-х годов XX века. Унаследовав национальный вопрос от Российской империи, советское руководство стремилось найти его собственное решение. Поэтому методы и формы национальной политики

${ }^{1}$ Государственный архив Российской Федерации (ГАРФ).Ф.5446.Оп.86.а.Д 12345. Л-1-112 
советского государства носили двойственный характер. «С одной стороны, национальное сознание целенаправленно побуждалось, а в отношении ряда народов формировалось, но под идеологическим и политическим контролем власти» (Лурье, 2011:148). Эта противоречивость советской национальной политики проявлялась также и в том, что при постановке тактических задач советское руководство легко шло на отход от прежних пропагандистских лозунгов. Подобная тактическая гибкость особенно наглядно проявилась в условиях войны 1941-1945 гг. Здесь имела место смена идеологической парадигмы. При этом необходимо отметить эфрфективность идеологической работы советского правительства. Пропагандистской агитацией были охвачены все граждане огромной страны. Вместо отвлеченных призывов к мировой пролетарской революции и интернациональному единству использовались другие образы. Были задействованы такие механизмы мотивации, как национальные чувства и апелляция к образам национальных защитников Отечества.

После нападения фрашистской Германии на СССР война приобретает оборонительный, а значит благородный характер защиты Отечества. Но здесь возникает очень важный и интересный нюанс - происходит определенная гуманизация пропагандистских лозунгов. Как советские граждане и товарищи в одночасье стали «братьями и сестрами великому вождю», так и образ Родины как общего социалистического отечества, становится конкретно твоим домом, твоим народом, который надо защитить. Еще одним исключительно правильным шагом пропагандистской работы стало обращение к исторической традиции защиты Отечества. Советское руководство не побоялось сделать поворот на сто восемьдесят градусов в идеологической работе. В одночасье, на некоторое время, были забыты принципы классового подхода. В качестве героев для подражания были провозглашены исторические личности классово чуждого для советской власти и социального происхождения - князья, аристократы ханы и батыры. Впервые за историю уже советского Казахстана лидер местной коммунистической партии Жумабай Шаяхметов в своей речи на митинге, посвященном началу мобилизации в июне 1941 года призвал казахских юношей обратиться к духу великих предков в лице хана Аблая и хана Кенесары. Точно такие же призывы прозвучали в другом документе Письме казахского народа воинам фронтовикам, под которым подписалась 3 миллиона казахстанцев. Текст письма был опубликован 23 февраля 1943 г. в газете «Правда», а также зачитан на казахском и русском языках по Всесоюзному радио (Все для фронта! 1985: 152).

Подобные призывы означали частичную реабилитацию ранее запретных страниц национальной истории, правда, на очень короткий срок. Колебание идеологического курса власти чутко отслеживалось национальными элитами, которые всегда использовали любую политическую возможность для восстановления и сохранения своего культурного наследия. Примером может служить попытка создания первого варианта советской редакции «Истории Казахстана с древнейших времен до наших дней», изданной при содействии эвакуированных ученых института истории РАН во главе с академиком А.М. Панкратовой. Концепция истории казахского народа авторского коллектива основывалась на осуждении колониальной политики царизма и положительной оценки национально-освободительного движения казахского народа. Особое внимание уделялось восстанию во главе с Кенесары Касымовым (1837-1847), как самом значительном в истории национально-освободительной борьбы казахского народа. 
В тот период реанимировались не только отдельные страницы казахской истории, но и формы устной поэтической традиции, героический эпос, творчество акынов и жырау, а также живая национальная традиция - казахский айтыс. Так, по инициативе Карагандинского обкома в 1942 г. началось проведение айтысов между районами. Только за период с 1942-1943 гг. состоялись десятки областных и республиканских айтысов, на которых выступали известные акыны импровизаторы: Ш. Кошкарбаев, К. Айнабеков, Н. Байганин. Они совершали своеобразные турне по городам и аулам, что имело большой агитационно-пропагандистский эффект (Козыбаев, 1991: 87).

Создание национальных воинских формирований находилось также в русле изменения вектора национальной политики в экстремальных условиях первого периода войны. Огромные потери личного состава Красной Армии к осени 1941 года требовали незамедлительных мер по скорейшей дополнительной мобилизации и ускоренной подготовки военно-обученных контингентов. Поиски внутренних резервов заставили Верховное командование искать новые и возрождать прежние формы военного строительства. Поэтому решением проблемы скорейшего восполнения людских ресурсов стало возвращение, как и в годы гражданской войны, к идее создания национальных воинских фрормирований. Согласно решению Государственного Комитета Обороны от 13 ноября 1941г, работа по подготовке резервов и фрормированию воинских частей для фронта должна была проводиться на местах под руководством местных партийных органов и командования военных округов. Сформированные в декабре 1941 г. части, были отправлены на фронт. С весны 1942 года в действующую армию стали прибывать национальные воинские соединения и части из Закавказья, республик Средней Азии, Казахстана, Башкирии и Татарстана. Военное руководство в лице Ставки, НКО и Генерального штаба оказалось вынужденным практически с нуля создать дополнительно новую армию. В то же время как специалист в национальном вопросе, Сталин и его окружение опасались, и не желали допускать чрезмерной военной самостоятельности национальных республик СССР. Национальные воинские соединения таили в себе реальную угрозу целостности многонационального государства. Этим объясняется, что 7 марта 1938 года постановлением ЦК ВКП (б) и СНК СССР «О национальных частях и фоормированиях РККА» был официально офрормлен и законодательно закреплен отказ от фрормирования национальных частей. Однако, к концу 1941 года, Красная Армия остро нуждалась в скорейшем пополнении личного состава действующей армии. В этих условиях восстановление национальных частей стало эфффективным и своевременным решением данной проблемы. Оно было принято Государственным Комитетом Обороны в виде постановления за № 894 от 13 ноября 1941 года «О формировании национальных войсковых соединений». Всего планировалось создать 20 кавалерийских дивизий и 15 отдельных стрелковых бригад. Из них в Башкирской АССР - 2 кавалерийские дивизии, в Туркменской ССР - одну кавалерийскую дивизию и одну отдельную стрелковую бригаду, в Узбекской ССР- 5 кавалерийских и 9 отдельных стрелковых бригад; в Таджикской ССР - 1 кавалерийскую и 2 отдельных стрелковых бригады; в Казахской ССР - 2 отдельные стрелковые бригады и 1 кавалерийскую дивизию; в Калмыцкой АССР - одну кавалерийскую дивизию; в Киргизской ССР - 3 кавалерийские дивизии; в Чечено-Ингушской и Кабардино-Балкарской АССР - по одной 
кавалерийской дивизии ${ }^{2}$. «Ввод в бой большинства национальных соединений пришелся на одну из наиболее тяжелых фраз Великой отечественной войны - летне-осеннюю 1942 г. наступательную кампанию немецко-фрашистских войск и их союзников. В результате к началу 1943 года удельный вес представителей неславянских национальностей в действующих войсках были наиболее высокими. Если сравнить представительство различных народов СССР в армии в апреле 1943 г. с данными переписи населения 1939 г., то окажется, что удельный вес этих народов в войсках значительно превышал их удельный вес среди населения СССР накануне войны. Так, к апрелю 1943 г. доля армян в войсках составляла 1,77\%, в то время как среди всего населения этот показатель не превышал 1,27 \%. Эти цифры для грузин составили 1,48 и 1,33 \%, азербайджанцев - 1,40 (на 1 июля 1943.-1,57) и 1, 34 \%, узбеков - 2, 62 и 2,86\%, казахов - 2, 22 (на 1 июля 1943 г.- 2,77) и 1.83 \%». (Безугольный, 2016:175).

Bсе вопросы формирования и комплектования национальных воинских подразделений находились в полной компетенции соответствующих республик. Это было серьезное важное правительственное задание в чрезвычайных условиях военного времени. Поэтому местные республиканские, областные, городские и районные комиссии, возглавляемые первым секретарем соответствующего партийного комитета (заместительпредседатель исполнительного комитета Совета депутатов трудящихся) со всей ответственностью проводили работу по отбору личного состава, обеспечению формировавшихся частей и соединений необходимым продовольствием, фруражом, обмундированием, снаряжением, транспортными средствами. В отчетах об этой работе нередко отмечается, что призыв в национальные формирования во многих местах проходил «исключительно на добровольных началах». «Призывники, отмечалось в справке - отчете Алмаатинского горкома партии, - были полны страстного желания вступить в национальную кавалерийскую дивизию или стрелковую бригаду». Подводя итоги работы по формированию национальных кавалерийских дивизий и стрелковых бригад в докладной записке ЦК КП (б) Казахстана был отмечен большой патриотический подъем, который проявился осенью 1941 г. "в массовой подаче заявлений с просьбой о добровольном зачислении в эти национальные формирования ${ }^{3}$.

Отличительной чертой казахских национальных фрормирований был высокий образовательный и морально-политический уровень призывников. Если в личном составе обычных кадровых формирований Красной Армии в 1941 - 1942 гг. партийно-комсомольская прослойка в среднем составляла 15$20 \%$, то в национальных кавалерийских дивизиях и стрелковых бригадах она оказалась значительно выше. К этому обязывали соответствующие решения партийных и комсомольских органов. «Для каждого коммуниста и комсомольца», - говорилось, например, в постановлении бюро Павлодарского обкома КП (б) Казахстана и облисполкома совета депутатов трудящихся, достойным ответом на постановление ГКО о разрешении формирования национальных войсковых соединений должна быть добровольность вступления в ряды национальных фрормирований». В результате национальные формирования республик Средней Азии и Казахстана состояли в среднем на $35-50 \%$ из коммунистов и комсомольцев. Национальные кавалерийские дивизии и стрелковые бригады получили кадры, обладавшие

\footnotetext{
${ }^{2}$ Российский Государственный архив социально-политической истории (РГАСПИ). Ф.644. Оп.1. Д.1.Л.1.

${ }^{3}$ Архив Президента Республики Казахстан (АПРК). Ф.708.Оп.5.Д.99.Л.63.
} 
немалым опытом организационной, политической, хозяйственной работы. Так, из 1190 руководящих работников, вступивших в казахские национальные формирования, 30 были из республиканских, 262 - из областных и 898 - из районных организаций. В их числе находились работники ЦК КП (б) Казахстана и СНК Казахской СССР, 7 секретарей обкома и 28 райкомов, более 40 заведующих отделами обкомов и райкомов КП (б) Казахстана (Козыбаев, 1991: 22).

Одной из причин возвращения к практике создания национальных формирований в Казахстане в 1941 году явилось также обострение проблемы знания русского языка со стороны «нерусского» контингента, который влился в армию в результате массовой мобилизации в национальных республиках в связи с необходимостью пополнить потерю людских ресурсов. Национальные войсковые формирования позволяли сократить сроки подготовки к боевым действиям контингента, не владевшего русским языком. Поскольку в национальных формированиях боевая и политическая подготовка велась на родном языке с учетом национальных обычаев и традиций, воинов казахов» (Козыбаев, 1991:23).

Незнание русского большинством призывников «нерусской» национальности, в частности казахов, способствовало нарушению внутриармейской коммуникации приводила к изоляции, ущемлению прав, фрормированию комплекса неполноценности. Поскольку официальным командным языком был русский, то от понимания команд и распоряжений командиров зависела эффективность и боеспособность воинского подразделения. Были случаи невыполнения приказа вследствие непонимания содержания команды. Воины казахи чувствовали себя «вторым сортом», поскольку недостаточно знали русский язык, не понимали русской ментальности. Положение усугублялось пренебрежительным, предвзятым отношением к воинам нерусской национальности со стороны некоторых командиров как неполноценным, неспособным хорошо сражаться бойцам. Подтверждением служит докладная записка начальника Управления агитации и пропаганды Глав.ПУРККА Рубенштейна начальнику Главного политического управления Красной Армии А.С. Щербакову: «...имеются факты проявления великодержавного шовинизма, не чуткого, порой грубого отношения к бойцам и младшим командирам нерусской национальности. Это ведет к тому, что в ряде случаев ...создается почва для чрезвычайных происшествий и аморальных явлений».... Политорганы не организовали изучение русского языка бойцами нерусской национальности. Это изучение, имеющее огромное политическое и военное значение, идет самотеком». Сложность и острота вопроса о воинах нерусской национальности в Красной Армии подтверждается тем фрактом, что в августе 1943 было организовано совещание агитаторов среди бойцов нерусских национальностей. В течение 20 - дней 192 агитатора, представлявших 24 национальности СССР слушали лекции ведущих советских историков и генералов армии, профессоров и академиков - И.И. Минца, А.М.Панкратовой, И.Ярославского. Примечательным является состав агитаторов: 50\% имели высшее образование, 30\% - среднее. (ЦК РКП(б), 2009; С. 758-759). Среди них были известные впоследствии деятели казахской культуры и науки, тогда политработники Красной Армии: А.Нусупбеков, С.Баишев, А.Закарин, К.Шарипов, Г.Абишев. Отдельные военачальники пытались решить проблему русского зыка посредством прямых связей. Так 1 ноября 1941 года выходит Постановление ЦК КП Казахстана об удовлетворении просьбы командующего Дальневосточным фронтом генерала Т.Апанасенко: 
«..., о призыве в Красную Армию и откомандировании на Дальневосточный фронт 250 коммунистов-казахов, хорошо знающих русский язык». Просьба отправить, молодых казахов коммунистов, хорошо владеющих русским языком, была связана с тем, что «... из Казахстана на Дальневосточный фронт мобилизовано значительное количество граждан из казахского населения, слабо знающих русский язык». Казахов-коммунистов необходимо использовать в качестве политработников в казахской воинской среде (Рассекреченная война, 2010: 124).

Особое внимание следует обратить на термин «нерусские народы» - это понятие официально фигурировало во всех документах военного времени, так или иначе затрагивавших национальные вопросы. Хотя, как таковой «нерусской национальности» не существовало, применяемый оборот свидетельствовал о том, что имело место своеобразная альтернатива русские как государственнообразующий народ и остальные народы СССР нерусские. По существу, это более мягкая замена прошлого имперского понятия «туземцы». Полагаем, что один из главных тезисов советской историографии об интернациональном единстве народов, требует корректировки. Поскольку реального равенства не было. Неравенство существовало, и оно официально закрепилось в послевоенный период в таких идеологемах как «русский народ первый среди равных» и «старший брат в братской семье народов». «Не русскость» означала незнание русского языка и русской культуры. В силу этих отличий они с трудом входили в русскоязычную армейскую общественность. Это способствовало формированию комплекса неполноценности в сознании казахского народа, который теперь должен был найти свое место в другой - русской культуре. «Второсортность» обосновывалась и другим широко пропагандируемым тезисом о вековой отсталости казахского народа, который к моменту прихода советской власти находился на грани вымирания, и только советская власть открыла путь к прогрессу и процветанию.

Тем не менее, создание национальных соединений сыграло свою роль в стимулировании мотивации казахских юношей к службе в армии. Эта служба рассматривалась казахской молодежью как реальная возможность личностного и социального роста. Стоит отметить, что аналогичная ситуация имела место в годы Первой мировой войны, когда в 1916 году, казахов призвали в армию, но не дали оружия и статуса полноценного солдата. Это вызвало волну возмущения и явилось одной из основных причин, приведших к восстанию 1916 года. Теперь же в ряды действующей армии призывались представители всех народов СССР независимо от социального положения и вероисповедания. Для казахского народа это было одним из первых признаков реального равноправия, показателем того, что власть считает их полноправными гражданами. Это, безусловно, способствовало патриотическому подъему казахского народа. В определенной степени вступление в ряды армии было осознанным выбором рекрутов из числа казахов. Воспоминаниях Мухамета Шаяхметова отмечалось: «... в то время, когда в Европе события 1939 рассматривали как начало войны, в Казахстане местное население относилось к этому как очередному конфликту». Когда в апреле 1941 года пришло время призыва в армию, то этот 19 летний парень даже не думал избегать его. Он отмечал, что поколение, которому он принадлежал, было поражено сталинской идеологией. Поэтому все пригодные юноши, получив приписные удостоверения, считали службу в армии чрезвычайно привлекательной. По мнению Шаяхметова, это было связано с 
патриотизмом, но не только. Очень высокой была степень социального признания военнослужащих. Как свидетельствует автор, их провожали на службу и встречали как героев. Сами они возвращались возмужалыми, в униформе, а победы 1939-1940 гг. повысили статус сталинской власти. Национальные проблемы у М. Шаяхметова возникли позже, когда он все -таки попал в ряды Красной армии в начале войны с Германией (Shayahmetov, 2006: 258).

Кроме того, здесь необходимо также отметить традиционно высокий статус ратного труда, воинской службы для казахского менталитета. Отношение к войне базировалось на сохранении элементов кочевнического сознания, которые, хотя и в фрагментарных формах, еще сохранялись в национальном менталитете. Воинская служба всегда рассматривалась кочевниками в качестве достойного занятия при условии, что государство дает воину оружие, обмундирование и доставляет к месту боевых действий. Для молодых людей военная служба выступала в качестве реального социального лифрта, предоставляла возможность быстрого общественного роста.

Еще одним фрактором успешной поведенческой мотивации - стало изменение религиозной политики власти. Реалии военного времени вынудили руководство партии отчасти пересмотреть свою политику в сфере религии. Руководство, страны в трагические первые месяцы войны вынужденно было стать лояльным к верующим, в том числе и к мусульманам. Причин, из-за которых атеистическая советская власть решилась повернуться лицом к религии было несколько. Во-первых, представители всех конфессий, в том числе и мусульмане с первых дней войны заняли открытую патриотическую позицию. Позабыв все гонения и преследования, верующие принимали самое активное участие в военных действиях, а также в сборе материальных средств для нужд Красной Армии. Исламские священнослужители помогли советскому руководству поднять моральный дух граждан Советского Союза мусульманского вероисповедания и мобилизовать их силы на борьбу с гитлеровским агрессором. В Докладной записке секретарю ЦКВКП(б) Г.М. Маленкову о патриотической роли мусульманского духовенства в годы войны говорится следующее: «...19 октября в Ташкенте закончил работу съезд представителей мусульманства Средней Азии и Казахстана. Одним из вопросов съезд заслушал доклад о патриотическом подъеме в работе духовенства. По этому вопросу было принято обращение ко всем верующим мусульманам. Делегат от Казахстана Аминов Абсолям, обращаясь к делегатам, заявил: «..я твердо уверен, что делегаты единодушно готовы защищать свою Родину, я очень рад, что в такое напряженное время нам предоставляют возможность созывать съезд. Будем молить бога, и просить Аллаха о скорейшей победе над фрашизмом». (ЦК РКП (б), 2009: 45).

Во-вторых, жесткий контроль общественного сознания, установленный сталинским режимом, а также подавление любых форм инакомыслия в условиях войны оказалось малоэффективным. На фронте и тылу имело место стихийное отправление религиозных обрядов. Многие верующие начали открыто высказывать свои религиозные взгляды, посещать молитвенные здания, игнорируя прежние запреты и ограничения. Обращение к традиционным духовным ценностям еще раз показало насколько тонкой и поверхностной была укорененность в общественном сознании советской атеистической идеологии. В-третьих, необходимость корректировки религиозной политики СССР была связана с международными интересами советского государства. Заинтересованность в открытии второго фронта 
требовала от советского руководства смягчения отдельных сторон жизни советского общества, чтобы выглядеть в лице мировой общественности более человечным и продемонстрировать приверженность общечеловеческим духовным ценностям. Черчилль и Рузвельт дали Сталину понять, что настроить общественное мнение их стран в пользу Советского Союза могут свидетельства о религиозной свободе в СССР. Неслучайно официальное признание властями заслуг религиозных организаций и верующих произошло накануне переговоров на высшем уровне в Тегеране.

В сентябре 1943 г. состоялась встреча И.В. Сталина с главами Русской православной церкви, в ходе которой были приняты решения, ознаменовавшие новый этап в отношениях государства и религии. На практике это выразилось в смягчении налогового законодательства в отношении зарегистрированных служителей культа, освобождении их от призыва по мобилизации, предоставлении религиозным организациям ограниченных прав юридического лица, а также в других мерах, предпринимаемых властями, по регулированию государственно-конфессиональных отношений.

В том же году к действующему Центральному духовному управлению мусульман (с центром в г. Уфре) были образованы еще три духовных управления мусульман - Северного Кавказа (Буйнакск), Закавказья (Баку) и Средней Азии и Казахстана (Ташкент). Это событие стало частью идеологической кампании, проводившейся советским руководством для воздействия на гражданские, патриотические чувства населения и для его мобилизации в военных условиях. Среди духовных управлений мусульман статус неформального лидера приобрело Среднеазиатское духовное управление, в ведении которого находилось единственное на территории СССР высшее мусульманское учебное заведение - медресе «Мир-Араб» (г. Бухара). 20 октября 1943 г. состоялся съезд мусульманских улемов Средней Азии и Казахстана, в котором приняли участие свыше 160 делегатов из всего региона.

Нельзя сбрасывать со счетов и такой ресурс власти как политикоправовые, или точнее, репрессивные методы, которыми пользовалась власть в чрезвычайных условиях военного положения. К ним относится серия, приказав ГКО о расширении карательных полномочий командиров в отношении солдат, а также жесткие методы контроля за трудовой дисциплиной в тылу, репрессивные методы депортации целых народов, уличенных в сотрудничестве с врагом. Продолжением репрессивной политики в условиях войны стало принятие 16 июля 1941 г. постановления ГКО, подписанного Сталиным, где отмечалось: «Государственный Комитет Обороны должен признать, что отдельные командиры и рядовые бойцы проявляют неустойчивость, паникерство, позорную трусость, бросают оружие и, забывая свой долг перед Родиной, грубо нарушают присягу, превращаются в стадо баранов, в панике бегущих перед обнаглевшим врагом». Далее шел список девяти высших командиров Западного, Севера-Западного и Южного фрронтов, расстрелянных за «трусость, бездействие власти, сдачу оружия противнику без боя» (Мультатули, Музафаров, 2016:130).

Степень влияния мотивации страхом в моральной мобилизации советских граждан достаточно новая тема в истории войны 1941-1945 гг. Интересным в этой связи является мнение российского исследователя М.А.Вылцана. Определяя основные фракторы поведенческой мотивации трудовой деятельности крестьянства в годы войны, он отмечает, что: «В поведенческой структуре крестьянства не последнее место занимало и 
ощущение страха неотвратимости наказания за неисполнение «своего гражданского долга», приказа высших и местных властей. (Вылцан, 1995: 74).

Это положение российского автора можно применить и к оценке мотивационных факторов казахских солдат, которые в основной своей массе были сельскими жителями. Поэтому есть основание предположить, что самоотверженный труд и воинская доблесть казахского народа не являются в полной мере следствием только патриотического подъема. Здесь, безусловно, имело место чувство страха, которое всегда является «стимулом» деятельности и поведения всего народа, следствием тоталитарного воспитания. Это своего рода гражданская реакция на сугубо насильственные, репрессивные методы государственного руководства, сопровождавшихся идеологической пропагандой. Этому также способствовала недавняя трагедия - насильственная коллективизация, в которой казахи были в роли пассивной жертвы советской модернизации. Все это не могло не сказаться на моральном состоянии казахского народа. Прямые физические потери как следствие коллективизации, современные историки квалифицируют как «этноцид», что нанесло тяжелейшую травму национальному сознанию. Она показала степень безжалостности новой власти. Полагаем, что добровольная жертвенность казахского народа в годы войны объясняется не только умело приводимой национальной политикой, эффективностью средств агитации и пропаганды, но также под давлением страха перед жестокой всемогущей властью. Мотивация страхом стала еще одним ресурсом власти в мобилизации населения.

Однако, как указывалось выше только репрессивные способы давления не могли быть достаточно эффективными в условиях, когда люди должны были добровольно жертвовать всем, включая собственную жизнь. В такой ситуации должны были быть задействованы более мощные факторы мотивации, чем страх перед наказанием. Таким фрактором стала новая «советская идентичность». Наличие такой категории в мировоззрении советских людей подтверждается свидетельством немецкого агента калмыцкого происхождения, засланного немецким командованием в зону оккупации Калмыкии для работы с местным населением в марте 1943 года. При встречах с молодыми калмыками он «обнаружил довольно сильный советский патриотизм, в особенности среди молодежи. Мне было трудно понять их аргументацию. Они говорили: «Мы конечно не коммунисты, но посмотрите - у нас есть своя республика, своя столица, свои министры, великолепный Дом Советов. Открылось множество школ». Прошедшие десять лет наложили на население сильный отпечаток, и этого нельзя было не принимать в расчет. Пути назад в прошлое уже не было. Я увидел перед собой поднимающийся новый тип человека, способного на многое, но умеющего приспосабливаться и подстраиваться под обстоятельства». (Гарвардский проект, 2018: 127).

Свидетельство калмыцкого агента констатирует формирование общей системы ценностей граждан большой страны, которая становится общей для всех независимо от национальной принадлежности. Это было единство народов, которое основывалось не только на официальной государственной доктрине. Но эта не та идентичность, которая провозглашалась властью и сталинским режимом. «Идеальный проект советского человека, как нового человека и дружба народов пропагандируемый государством, официальной идеологией, преломляясь через этническое восприятие и необходимость адаптировать эту идеологему для повседневной жизни и практики привели к созданию собственной модели отношений и идеального образа, который не 
есть точное воплощение официальной политики властей, но во многом приближенная к ней собственная культурная форма». (Лурье, 2011:8).

Это были горизонтальные человеческие связи, которые существовали параллельно официальной государственной доктрине о «дружбе народов» и «братском единстве». Единство народов, объединенных общей трагической судьбой и вынужденных жить и выживать в тяжелейших условиях тоталитарного режима. Это была взаимопомощь народов, которые оказались в беде, и с которыми казахи делили общие тяготы жизни под «всевидящим оком» жестокой власти. Имеется много примеров взаимопомощи и поддержки народов Советского Союза. Дружба народов и советская идентичность к началу войны стали реальностью, которая явилась одним из факторов патриотической мотивации казахских солдат, которые пошли защищать общую страну как советские люди. Не официальная, насаждаемая правящей властью система ценностей, а спонтанно сфрормировавшаяся система отношений. В огромной стране, куда вместе с другими народами входили казахи, положение простых людей было равным - все были одинаково равны в своем бесправии и зависимости от вездесущей власти. Казахи вместе с другими народами СССР вместе выстрадали тяготы становления советского государства, более того, в далекие исторические времена они всегда были соседями, всегда жили рядом. Общность исторического прошлого порождала чувство единства трудной судьбы. Это не до конца осознаваемое чувство, больше чем офицциальные идеологемы сближало народы СССР. Поэтому патриотизм казахских солдат наряду с другими факторами, мотивировался этим чувством. Единство советских людей было единством народов, вместе вставших на защиту общего государства, которое оказалось в трудном положении.

Казахские солдаты пошли защищать не коммунистический режим и даже не социалистическое отечество - они разделили судьбу народов, оказавшихся в одном тоталитарном государстве и с честью выполнили свой воинский и соседский долг. Этот фрактор мобилизационной мотивации проявился позже всех, и он не имел ничего общего с политикой государства. Но это была инициатива «снизу» как всенародное явление. Однако, значение этого фактора в моральной мобилизации воюющего народа важнее, чем все усилия власти. Поэтому автор считает, что Победа в Отечественной войне 1941-1945 гг. была одержана советским народом не благодаря советской власти и руководству И.В. Сталина, а вопреки ему. Это была народная победа.

Заключение. Изучение вопроса об основных фракторах поведенческой мотивации казахских солдат в годы Великой Отечественной войны на примере национальных воинских фрормирований требует специального комплексного изучения. В данном случае имеет место попытка постановки проблемы и обозначение основных векторов исследовательского поиска, внутренних причин самоотверженного поведения казахских воинов на полях сражений. Война, как событие экстремальное, обнажило многие слабые места советской внутренней и внешней политики. Суровая военная действительность показала насколько реальное положение отличается от той радужной картины, которую рисовала советская пропаганда. Большинство провозглашенных достижений оказались не жизнеспособными. Эти просчеты и ошибки советской власти учитывали и немецкие военачальники, надеясь, что как только войска вермахта перейдут границу СССР советское правительство будет свергнуто собственным народом. Однако этого не произошло. В результате своевременной перестройки национальной политики советское государство смогло обеспечить быструю моральную мобилизацию населения 
национальных республик. Поскольку от них во многом зависело спасение страны в первые критические месяцы войны. в годы войны фрактически произошла определенная десталинизация режима. Это явление продолжалось недолго и сразу же после коренного перелома в ходе войны, т.е. начиная с 1943 сталинский режим начал восстановление прежде сданных позиций. Апелляция к традиционным национальным и религиозным ценностям национального сознания позволил власти использовать духовный подъем народа, который добровольно пошел на неисчислимые жертвы. Создание национальных воинских формирований, и казахских в том числе, так же является свидетельством перемены содержания национальной политики, связанной с военной действительностью. Таким образом, мы можем констатировать, что в условиях начавшейся войны, особенно в первый критический период в деле идеологической пропаганды произошел коренной поворот. Большинство методов репрессивной политики оказался бездейственным в условиях войны. Управлять силой людьми, которые каждый день должны добровольно рисковать жизнью невозможно. Здесь действует только фрактор добровольности и осознанного поведения. При этом произошел отход от прежней идеологии пролетарского интернационализма в сторону национально - патриотической идеологии. Это был вынужденное обращение к национальной тематике, причем не просто национальной, а исторического национального прошлого. Вместе с тем нельзя полностью игнорировать такой ресурс советской власти как репрессии и жестокое подавление инакомыслия. Военное положение облегчало использование всей силы репрессивной машины. Мотивация страхом являлся важным фрактором поведенческой моральной мобилизации казахских солдат. Добровольная жертвенность казахского народа в годы войны, объясняется не только умело проводимой национальной политикой, но и эфффективностью средств пропаганды и агитации.

Таким образом, реальная картина моральной мобилизации и патриотического подъема казахских солдат обусловлена целым рядом причин и представляет собой сложный социо-культурный процесс в котором государственная политика и народное сознание не всегда совпадали, но в итоге привели к Победе.

\section{Әдебиеттер тізімі/ Список литературы}

1. Алдажуманов,2011 - Алдажуманов К.С. История войны 1941-1945 годов и Казахстан: «белые пятна» и проблемы // Социогуманитарная наука Казахстана. Алматы, 2011.

2. Балакаев, Алдажуманов,1989 - Балакаев Т.Б., Алдажуманов К.С. Историографиия Казахстана периода Великой Отечественной войны // Актуальные проблемы истории Советского Казахстана. Алма-Ата,1989.

3. Бивор, 2016 - Бивор Э. Вторая мировая война. М., 2016. 1450 с.

4. Безугольный, 2016 - Безугольный А. «Источник дополнительной мощи Красной Армии». // Национальный вопрос в военном строительстве в СССР 1922-1945. М.: РОССПЭН, 2016. 271с.

5. Вылцан, 1995 - Вылцан М.А. Приказ и проповедь: способы мобилизации ресурсов деревни в годы войны // Отечественная история. 1995. № 3.

6. Все для фронта, 1985 - Все для фронта все для Победы! // Алма-Ата: Казахстан,1985.

7. Гарвардский проект, 2018 - Гарвардский проект: Рассекреченные свидетельства о Великой Отечественной войне. М.: РОССПЭН, 2018. 493 с.

8. Гланц, 2008 - Гланц Д. Советское военное чудо 1941-1943. Возрождение Красной Армии. М.: Яуза, Эксмо, 2008. 640 с.

9. Козыбаев, 1991 - Козыбаев М.К. Великая Отечественная война: истоки Победы / История и современность. Алма-Ата: Гылым, 1991. 266 с. 
10. Козыбаев, 2000 - Козыбаев М.К. Казахстан на рубеже веков: размышление и поиски. Алматы, 2000. 417 с.

11. Козыбаев, 1991 - Козыбаев М.К., Белан П.С. Казахстанская историография Великой Победы аналитический обзор. ОНИОН АН Казахской ССР, 1991. 30 с.

12. Книга Памяти Казахстана, 1995 - Книга Памяти Казахстана - Боздақтар. Сводный том. Сост: Белан П.С., Едыгенов Н.Е. Алматы, 1995. 518 с.

13. Лурье, 2011 - Лурье С.В. «Дружба народов» в СССР: национальный проект или пример спонтанной межэтнической самоорганизации» // Общественные науки и современность. 2011. №4. C. $145-153$.

14. Мультатули, Музафаров, 2016 - Мультатули П.В., Музафраров А.А. Великая Отечественная война. Победа духа и традиции. М.: РИСИ, 2016.

15. Рассекреченная война, 2010 - Рассекреченная война: «особые папки» ЦКП (б) Казахстана 1941-1945. (Сб. документов). Алматы, 2010.

16. Тишков, 1993 - Тишков В.А. Стратегия и механизмы национальной политики в Российской Федерации // Этнографическое Обозрение. 1993. №5. С. 12-34.

17. ЦК РКП(б) - ВКП(б) и национальный вопрос 1933-1945. Т. 2. М.: РОССПЭН, 2009.1094 с.

18. Shayahmetov, 2006 - Shayahmetov M. The Silent Steppe. The Memoir of a Kazakh Nomad under Stalin. New York, 2006. 266.c.

\section{References}

Aldazhumanov,2011 - Aldazhumanov K.S. Istoriya vojny 1941-1945 godov i Kazahstan: «belye pyatna» i problemy // Sociogumanitarnaya nauka Kazahstana. Almaty, 2011. (in Rus.)

Balakaev, Aldazhumanov,1989 - Balakaev T.B., Aldazhumanov K.S. Istoriografiya Kazahstana perioda Velikoj Otechestvennoj vojny // Aktual'nye problemy istorii Sovetskogo Kazahstana. AlmaAta, 1989. (in Rus.)

Bivor, 2016 - Bivor E. Vtoraya mirovaya vojna. M., 2016. 1450 s.(in Rus.)

Bezugol'nyj, 2016 - Bezugol'nyj A. «lstochnik dopolnitel'noj moshchi Krasnoj Armii». // Nacional'nyj vopros v voennom stroitel'stve v SSSR 1922-1945. M.: ROSSPEN, 2016. 271 c.(in Rus.)

Vylcan, 1995 - Vylcan M.A. Prikaz i propoved': sposoby mobilizacii resursov derevni v gody vojny // Otechestvennaya istoriya. 1995. № 3. (in Rus.)

Vse dlya fronta, 1985 - Vse dlya fronta vse dlya Pobedy! // Alma-Ata: Kazahstan,1985. (in Rus.)

Garvardskij proekt, 2018 - Garvardskij proekt: Rassekrechennye svidetel'stva o Velikoj Otechestvennoj vojne. M.: ROSSPEN, 2018. 493 s.(in Rus.)

Glanc, 2008 - Glanc D. Sovetskoe voennoe chudo 1941-1943. Vozrozhdenie Krasnoj Armii. M.: YAuza, Eksmo, 2008. 640 s.(in Rus.)

Kozybaev, 1991 - Kozybaev M.K. Velikaya Otechestvennaya vojna: istoki Pobedy / Istoriya i sovremennost'. Alma-Ata: Gylym, 1991.266 s.(in Rus.)

Kozybaev, 2000 - Kozybaev M.K. Kazahstan na rubezhe vekov: razmyshlenie i poiski. Almaty, 2000. $417 \mathrm{~s}$.

Kozybaev, 1991 - Kozybaev M.K., Belan P.S. Kazahstanskaya istoriografiya Velikoj Pobedy analiticheskij obzor. ONION AN Kazahskoj SSR, 1991. 30 s.(in Rus.)

Kniga Pamyati Kazahstana, 1995 - Kniga Pamyati Kazahstana - Bozdaқtar. Svodnyj tom. Sost: Belan P.S., Edygenov N.E. Almaty, 1995. 518 s.(in Rus.)

Lur'e, 2011 - Lur'e S.V. «Druzhba narodov» v SSSR: nacional'nyj proekt ili primer spontannoj mezhetnicheskoj samoorganizacii» // Obshchestvennye nauki i sovremennost'. 2011. №4. C. 145153.(in Rus.)

Mul'tatuli, Muzafarov, 2016 - Mul'tatuli P.V., Muzafarov A.A. Velikaya Otechestvennaya vojna. Pobeda duha i tradicii. M.: RISI, 2016.(in Rus.)

Rassekrechennaya vojna, 2010 - Rassekrechennaya vojna: «osobye papki» CKP (b) Kazahstana 1941-1945. (Sb. dokumentov). Almaty, 2010.(in Rus.)

Tishkov, 1993 - Tishkov V.A. Strategiya i mekhanizmy nacional'noj politiki v Rossijskoj Federacii // Etnograficheskoe Obozrenie. 1993. №5. S. 12-34.(in Rus.)

CK RKP(b) - VKP(b) i nacional'nyj vopros 1933-1945. T. 2. M.: ROSSPEN, 2009.1094 s.(in Rus.)

Shayahmetov, 2006 - Shayahmetov M. The Silent Steppe. The Memoir of a Kazakh Nomad under Stalin. New York, 2006. 266.s. 